\section{Nauplius}

The Journal of The

Brazilian Crustacean Society

e-ISSN 2358-2936

www.scielo.br/nau www.crustacea.org.br

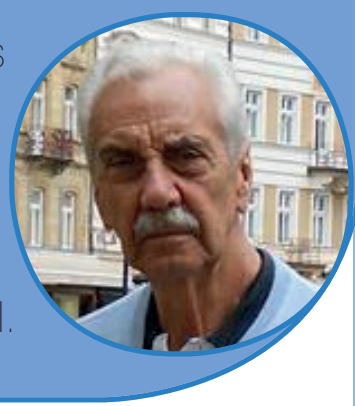

\title{
Reproductive investment and multiple spawning evidence in the redfinger rubble crab Eriphia gonagra (Brachyura, Eriphioidea)
}

\author{
Gustavo M. Teixeira', Vivian Fransozo², João M. Góes ${ }^{3}$, \\ Lissandra C. Fernandes-Góes ${ }^{4}$, Gustavo L. Hirose ${ }^{5}$, \\ Ariádine C. Almeida ${ }^{6}$ and Adilson Fransozo ${ }^{7}$ \\ ${ }^{1}$ Universidade Estadual de Londrina, Departamento de Biologia Animal e Vegetal. \\ Londrina, Paraná, Brazil. \\ ${ }^{2}$ Universidade Estadual do Sudoeste da Bahia, Campus de Vitória da Conquista, \\ Departamento de Ciências Naturais. Vitória da Conquista, Bahia, Brazil. \\ ${ }^{3}$ Universidade Federal do Piauí. Parnaíba, Piauí, Brazil. \\ ${ }^{4}$ Universidade Estadual do Piauí. Parnaíba, Piauí, Brazil. \\ ${ }^{5}$ Universidade Federal de Sergipe, Departamento de Biologia. Aracaju, Sergipe, Brazil. \\ ${ }^{6}$ Universidade Federal de Uberlândia, Instituto de Biologia, Campus Umuarama. \\ Uberlândia, Minas Gerais, Brazil. \\ ${ }^{7}$ Universidade Estadual Paulista, Instituto de Biociências, Departamento de Zoologia. \\ Botucatu, São Paulo, Brazil.
}

ZOOBANK http://zoobank.org/urn:lsid:zoobank.org:pub:08E6BBEF-6276-41D6AD81-A669D0164031

CORRESPONDING AUTHOR Gustavo M. Teixeira gmteixeira@uel.br

SUBMITTED 25 February 2016 ACCEPTED 20 October 2016 PUBLISHED 27 Abril 2017

Guest Editors

Maria Lúcia Negreiros-Fransozo and Adilson Fransozo

DOI 10.1590/2358-2936e2017006

\section{Abstract}

The variation in reproductive investment (RI) and the hypothesis of multiple spawning were evaluated in the redfinger rubble crab Eriphia gonagra (Fabricius, 1781). The gonads and embryos showed synchronous development, and fecundity and RI varied widely among females of the same size class. The mean RI value recorded was $11.31 \%$, with no significant differences among the means for different size classes. The allometric analysis of fecundity indicated RI decrease while body size increase, but we suggested that this occurs due to size overestimation where the largest width of carapace 
was used as body size reference in these analyzes. In addition, we found an isometric relationship for "female weight $v s$. egg number", and also for "female weight $v s$. egg weight", indicating that RI increased proportionally with size of females. Relatively high frequencies both of smaller females with rudimentary gonads, and of larger females with developed gonads were observed. This indicates that larger females take place more frequently in the population reproductive output over time. This difference could not be observed by means of RI analyses of captured and fixed crabs, for which only one stage of gonad development and/or one spawning is usually recorded.

\section{KEY WORDS}

Decapoda, allometric analysis, fecundity, reproductive effort.

\section{INTRODUCTION}

Reproductive patterns vary widely among brachyurans. Some species reproduce in the intermolt period, while others breed immediately after females molt; many species spawn only once during a reproductive season, while others can spawn more frequently (Hartnoll, 1982). Multiparous brachyuran females retain viable sperm and do not need to copulate prior to each spawning; hence they are likely to store sperm from more than one male in their seminal receptacles (Diesel, 1991). Some species produce gametes more or less continuously, and the sequential production of offspring is interrupted only during the incubation period (Reigada and Negreiros-Fransozo, 2000). The occurrence of ovigerous females with fully grown gonads, which indicates that more than one spawning occurs in a single intermolt period (Choy, 1988; Sumpton, 1990), and observations of variability in fecundity among females of similar sizes have been attributed to the occurrence of multiple spawning, although these inferences are only speculative (Leme, 2006).

In brachyurans, fecundity is usually evaluated in relation to the crabs' size or weight, to environmental variations, to the brood survival rate, or even to the ability to accumulate yolk in the thoracic cavity (e.g., Hines, 1982; Jones and Simons, 1983; Du Preez and McLachlan, 1984; Branco and Avilar, 1992; Mantelatto and Fransozo, 1997; Santos and Negreiros-Fransozo, 1997; Góes et al., 2005; Hines, 2011; Antunes et al., 2015). Fecundity is a volumetric dimension and female size is a linear measure. The slope based on the allometric model should approximate 3.0 (i.e., $b=3.0$ ), and the intercept will represent the absolute number of eggs, independently of female size ( $a$; see White and Gould, 1965; Wootton, 1979). Consequently, slopes differing from 3.0 imply the absence of a simple volumetric relationship (Somers, 1991).

In female crabs, the content of oocytes in the ovaries is displayed during spawning. After fertilization, the eggs are deposited on the pleopod setae, where they remain until the end of the incubation. Thus, a female's investment in a particular spawning can be determined in two ways: by measuring the fully developed ovaries, or by counting the eggs in the exteriorized egg mass (Hartnoll, 1996).

According to Bryant and Hartnoll (1995), the energy investment in the reproduction process can be measured by means of the reproductive effort, e.g., by the specific size of the reproductive output per unit of time. In brachyurans, investment per brood in dry weight terms has a mean of about $10 \%$ (Hines, 1982; Brante et al., 2004). The number of eggs per spawning per breeding season is complementary and necessary information for understanding the contribution of a single female to its natural stock.

The majority of the literature concerning multiple spawning in crabs refers to the Majoidea, probably because most species of this group are economically important, and also because they show determinate growth (terminal anecdysis) (Hartnoll, 1963). With reference to the Xanthoidea, Morgan et al. (1983) found that Rhithropanopeus harrisii (Gould, 1841) is able to retain viable spermatozoa while spawning repeatedly after a single copulation. Morgan and collaborators also mentioned the possible ecological significance of spermatophore retention. Synchrony between gonad and embryo development has been observed in southwestern Atlantic crabs such as the portunoids Portunus spinimanus Latreille, 1819 
and Callinectes danae Smith, 1869 (see Santos and Negreiros-Fransozo, 1997; Costa and NegreirosFransozo, 1998), and the aethroid Hepatus pudibundus (Herbst, 1785) (see Reigada and Negreiros-Fransozo, 2000). They noted the capacity of these species for multiple spawning in a single reproductive year-season. However, little information is available on this subject for the representatives of the Eriphiidae.

Eriphia gonagra (Fabricius, 1781) is a common crab in the intertidal zone on the northern coast of São Paulo State, Brazil and it can be find in rocky shores or living associated with colonies of Phragmatopoma (Polychaeta, Sabellariidae) (Andrade et al., 2014). The available knowledge on this species is related to larval and juvenile development (Fransozo, 1986; Fransozo and Negreiros-Fransozo, 1986; 1987; 1991); heterochely, sex ratio, relative growth (Góes and Fransozo, 1997; 1998; 2000, respectively), fecundity (Góes et al., 2005) and differential habitat use by demographic groups (Andrade et al., 2014). The multiple spawning was suggested to occur in this species (Góes et al., 2005), but no conclusive evidence was provided by authors.

The present study aimed to analyze the variation of reproductive investment in relation to females' size of E. gonagra, verify the frequency of non-ovigerous females in different size classes considering their gonad stages and evaluate the synchrony between gonad and embryo development as a multiple spawning evidence. Additionally, we propose a reanalysis of fecundity data presented by Góes et al. (2005), where we used allometric equation to extract information, which agrees with the reproductive investment variation.

\section{Material and Methods}

Females of E. gonagra were sampled monthly during 1996 and 1997, by scanning the rocky shore of “Praia Grande" beach ( $23^{\circ} 28^{\prime} 02^{\prime}$ "S $\left.45^{\circ} 03^{\prime} 35^{\prime \prime} \mathrm{W}\right)$ at Ubatuba, São Paulo. The crabs were collected by hand, with a capture effort by two people for two hours. In the laboratory, the specimens were counted and the carapace width $(\mathrm{CW})$ measured with a caliper $(0.01 \mathrm{~mm})$. Immature females were not utilized in the analysis. The mature females were grouped as ovigerous and non-ovigerous. The crabs were dissected, and the developmental condition of the gonad was recorded by macroscopic observation. The gonads were classified in three developmental stages, based on the shape, volume, and color of the ovaries: rudimentary (RU), with whitish or translucent ovaries, with no evidence of vitellogenesis; developing (ED), with light-yellow ovaries, indicating yolk accumulation in the oocytes during primary vitellogenesis; and developed (DE), with oocytes filled with yolk during secondary vitellogenesis (adapted from Johnson, 1980; Choy, 1988; Abelló, 1989).

Eggs were classified in three embryonic developmental stages: I initial (IN), eggs orange, indicating a large amount of yolk; II intermediate (INT), eggs light brown and compound eyes visible under the microscope; III final (FIN), eggs dark gray, zoeae visible under the microscope (based on Santos and Negreiros-Fransozo, 1997).

The pleopods of the ovigerous females were cut at their base and fixed in 70\% ethanol. The eggs adhered to the pleopods were immersed in a solution of 5-6\% sodium hypochlorite $(\mathrm{NaClO})$, and then separated using a mechanical shaker. Because this species bears a large number of eggs, a subsample obtained with a Motoda sampler (Motoda, 1959) was counted. The eggs were counted under a stereoscopic microscope, using a manual counter, and the total egg number (EN) was calculated for the whole egg mass. The females and their egg masses were dried in an oven, and the dry weight of the females (FW) and the eggs (EW) were measured on a precision balance $(0.001 \mathrm{mg})$.

The ovigerous females were sorted into three groups according to the developmental stage of their eggs (IN, INT, and FIN). After that, each group was again subdivided according to the gonad development (RU, $\mathrm{ED}$, and $\mathrm{DE}$ ). These data were plotted on a histogram and compared by means of Goodman's test $(\alpha=0.05)$ (Curi and Moraes, 1981), which evaluates contrasts between binomial proportions. All mature females were grouped in seven size classes with amplitude of 4.2 $\mathrm{mm} \mathrm{CW}$, the same interval used by Góes et al. (2005).

The fecundity variation was evaluated by calculating the mean and standard deviation of the fecundity, and the fecundity index (FI) with maximum and minimum values $(\mathrm{FI}=\mathrm{EN} / \mathrm{CW})$ for each size class. These features were compared among females' size class, using Kruskal-Wallis test followed by Dunn's test (Zar, 1999). 
The reproductive effort as a function of the crab size (CW) vs. female weight was evaluated by means of an allometric technique. Prior to this analysis, the data (CW, FW, EW and EN) were log-transformed. The transformed data were fitted to an allometric equation: $\mathrm{Y}=\mathrm{a}+\mathrm{bX}$; where $\mathrm{X}=\log (\mathrm{CW}$ or weight $)$ and $\mathrm{Y}=$ $\log (\mathrm{EW}$ or EN), and "a" and "b" are constants that indicate the intercept and the slope, respectively. The allometry level is indicated by the " $b$ " value $(b=3$ indicates isometry, and $b \neq 3$ indicates allometry for the relationship between carapace width and number of eggs (Somers, 1991); or $b=1$ indicates isometry, and $b \neq 1$ indicates allometry for the relationship between female weight and egg weight).

The non-ovigerous adult females, grouped in size classes, were also plotted on a histogram according to the gonad development (RU, ED, and DE). The values for frequency of occurrence were compared by means of Goodman's test $(\alpha=0.05)$ (Curi and Moraes, 1981).

The female crabs' reproductive investment in terms of egg mass can be determined in two ways: by measuring the ripe ovaries, or by measuring the newly laid egg mass (Hartnoll, 1996). Here we chose the second option. For comparative purposes, the investment was expressed as a percentage of the female body size. The RI (reproductive investment) was compared among size classes by ANOVA followed by Tukey test (Zar, 1999).

\section{ResULTS}

A total of 417 females of E. gonagra were obtained, of which 121 were immature, 90 ovigerous, and 206 non-ovigerous. Proportions of females with gonads in different stages within each group of embryonic stage showed significant differences (Fig. 1). In short, ovigerous females with eggs in IN embryonic stage had a smaller proportion of gonads in $\mathrm{DE}$ (Goodman's test, $\mathrm{p}<0.05)$. This pattern tended to change for females that showed INT embryonic development: a higher proportion of these females were in ED gonad stage (Goodman's test, $\mathrm{p}<0.05$ ). A higher proportion of females with FIN embryonic development were in $\mathrm{DE}$ gonad stage (Goodman's test, $\mathrm{p}<0.05$ ).

Fecundity index (FI) varied from 141.26 to 876.31 , with a mean of $514.57 \pm 185.08$. The FI showed significant differences among size classes (KruskalWallis, $\mathrm{p}<0.001$ ), with the highest mean values in the larger size classes (Fig. 2).

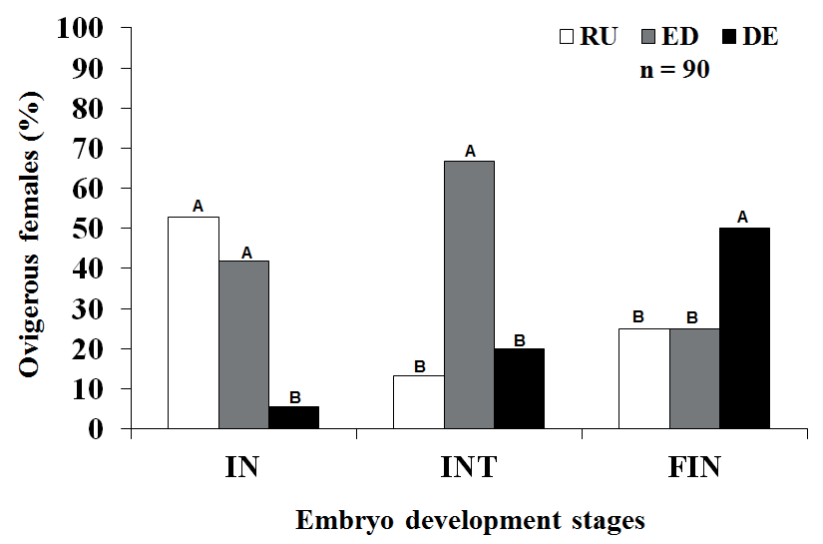

Figure 1. Eriphia gonagra (Fabricius, 1781). Ratio of ovigerous females in each gonad development stage (RU = rudimentary, $\mathrm{ED}=$ developing, $\mathrm{DE}=$ developed) compared within the groups of females in each embryo development stage (IN = initial, INT $=$ intermediate, $\mathrm{FIN}=$ final). Bars with same letter did not differ statistically (Goodman's test; $\alpha=0.05$ ).

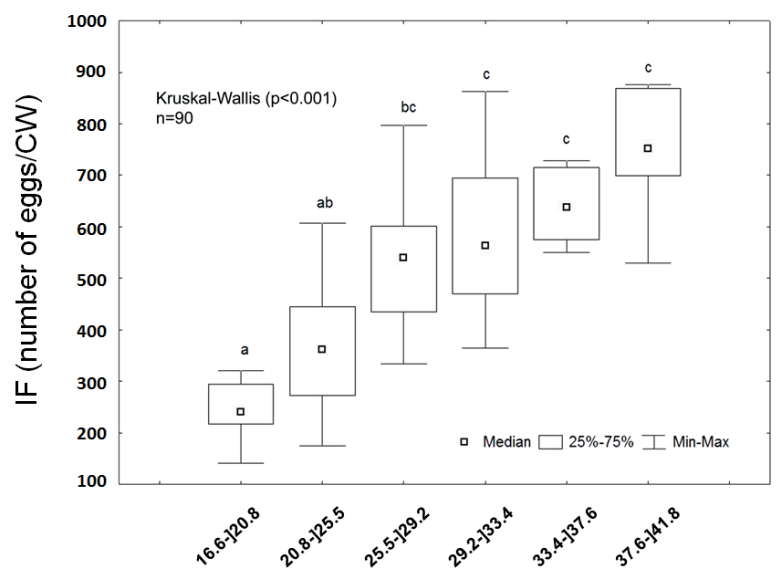

Size classes of CW $(\mathrm{mm})$

Figure 2. Eriphia gonagra (Fabricius, 1781). Fecundity index (FI) values (median, standard deviation, and maximum and minimum) for each size class. Median with same letter did not differ statistically (Kruskal-Wallis test; $\alpha=0.05$ ).

The relationship CW vs. egg number (Fig. 3A) showed significant negative allometry $\left(\mathrm{p}<0.05 ; \mathrm{t}_{\mathrm{tab}}=\right.$ 1.66; $\mathrm{t}_{\text {cal }}=1.68$ ). The relationship FW vs. EN (Fig. 3B) showed isometry $\left(\mathrm{p}>0.5 ; \mathrm{t}_{\mathrm{tab}}=1.66 ; \mathrm{t}_{\mathrm{cal}}=0.33\right)$, and the relationship FW vs. EW (Fig. 3C) also showed isometry $\left(\mathrm{p}>0.5 ; \mathrm{t}_{\mathrm{tab}}=1.66 ; \mathrm{t}_{\text {cal }}=0.27\right)$.

The estimated total mean reproductive investment (RI) was $11.31 \%$, but showed marked variation within each size class, and low variation in the mean values among all size classes (Fig. 4). The mean values of RI did not differ significantly among size classes (ANOVA, $\mathrm{p}<0.05)$.

The analysis of frequency of occurrence of the different gonad developmental stages among size 

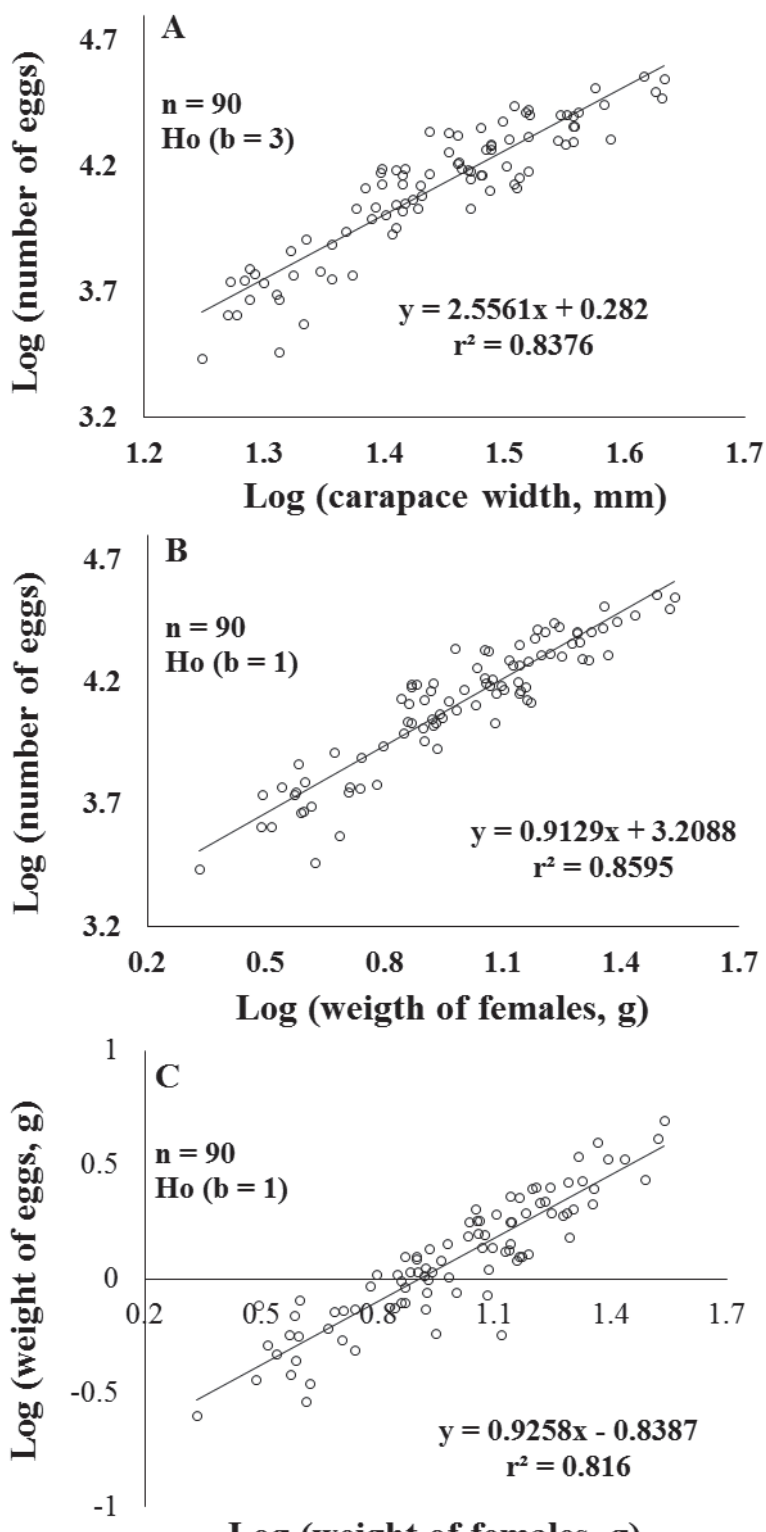

Log (weight of females, g)

Figure 3. Eriphia gonagra (Fabricius, 1781). Allometric relationships: A. log egg number (EN) vs. log carapace width (CW); B. log egg number (NE) vs. log female weight (FW); and C. log eggs weight (EW) vs. female weight (FW).

classes showed a higher proportion of smaller females in the RU stage (Goodman's test, $\mathrm{p}<0.05$ ). This pattern changed gradually as the females increased in size, and larger females had gonads in the DE stage (Fig. 5).

\section{Discussion}

In E. gonagra, gonads and embryos showed synchronous development, and fecundity and RI varied widely among females of the same size class. The mean RI value recorded was $11.31 \%$, with no significant differences among the means for different females' size

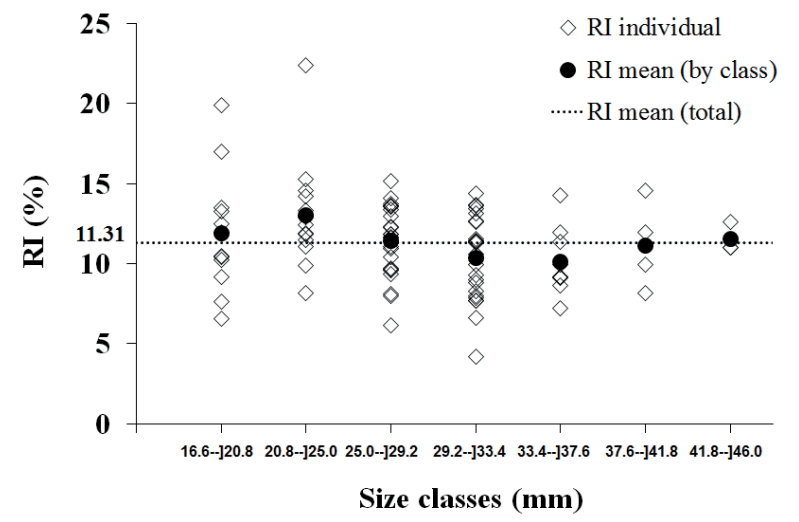

Figure 4. Eriphia gonagra (Fabricius, 1781). Reproductive investment (RI) by size class.

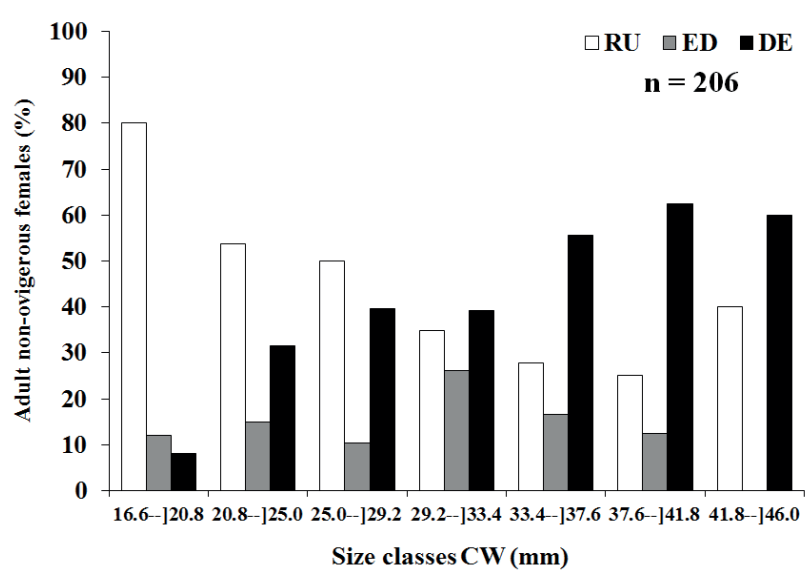

Figure 5. Eriphia gonagra (Fabricius, 1781). Ratio of nonovigerous adult females in the different gonad stages, by size class $(\mathrm{RU}=$ rudimentary, $\mathrm{ED}=$ developing, $\mathrm{DE}=$ developed $)$.

classes. The confirmation of the synchrony between female gonad and embryo development indicated that this species has multiple spawning, because after their eggs hatched, the females had gonads in an advanced stage of development, and could then exteriorize a new egg mass.

The adaptive significance of spermatozoon retention has been studied from different points of view. Subramonian (1991) stated that females are able to store spermatophores until their gonads are completely developed; and Biscoito et al. (2016), studying Chaceon affinis (Milne-Edwards \& Bouvier, 1894), found spermatophores inside spermatheca of females in carapace stages II and III suggesting that spermatophores are viable and used during the intermoult period. According to Cheung (1968), the capacity for spermatozoon retention affects the reproductive ecology of crabs; for instance, females 
of Menippe mercenaria Say, 1818 can produce more than 10 egg masses during one intermolt period, with only one mating. As observed by Flores and Paula (2010), two crab species [Xantho incisus Leach, 1814 and Pachygrapsus marmoratus (Fabricius, 1787)] from rocky intertidal area breed intensively producing multiple broods within a single intermoult stage. Possibly this process occurs by the similar way in $E$. gonagra. If the female reproductive activity ceased just after the larvae are released, there would be no reason to synchronize energy investment between ovarian development, yolk production, and incubation, because in most crabs mating occurs after the females have recently molted. A short space of time between larvae hatching and the next spawning may indicate that if a period of exhaustion occurs, it tends to be very short and therefore less important to the reproductive cycle as a whole (Rotlland et al., 2007).

In E. gonagra, the egg number and the female carapace width are positively and significantly associated $\left(r^{2}=0.84\right)$ (Góes et al., 2005). Species of Eriphia Latreille, 1817 already studied on this subject showed number of eggs related to the size of the individual crab, such as Eriphia smithii MacLeay, 1838 (Vannini and Gherardi, 1988; Tomikawa and Watanabe, 1992) and Eriphia verrucosa (Forskål, 1775) (Karadurmus and Aydin, 2016). Those crabs are large and carry many eggs when compared with E. gonagra, as found by Góes et al. (2005) (see Tab. 1).

Variation in the intraspecific fecundity in females of similar size has been reported for other brachyurans: $H$. pudibundus studied by Reigada and Negreiros-Fransozo (1995), P. spinimanus by Santos and NegreirosFransozo (1997), Callinectes ornatus Ordway, 1863 by Mantelatto and Fransozo (1997), C. danae by Costa and Negreiros-Fransozo (1998), and Aratus pisonii (H. Milne Edwards, 1837) by Leme and NegreirosFransozo (1998). This variation has been attributed to environmental and biotic factors such as temperature, photoperiod, salinity, and the nutritional state of the females.

Assuming that in the case of multiple spawning, the number of eggs tends to decrease in the later spawning, the wide variation in the number of eggs produced and the high standard deviation for the fecundity of females in each size class found for this species could be related to multiple spawning. As Adiyodi and Adiyodi (1970) suggested, the antagonism in use of energy resources between the processes of molting and gamete production may be a factor that increases the variability in fertility.

Bryant and Hartnoll (1995) assumed that the first egg mass produced by a female immediately after the puberty molt would be smaller than egg masses in subsequent spawning, because the female would have expended large amounts of energy during molting and growth. This mechanism is evident in the representatives of Majoidea, because of their determinate growth. Nevertheless, even if one considers that E. gonagra has indeterminate growth, the first spawning after a molt could be smaller than the next spawning, for the same reason. Therefore, comprehension of the patterns of reproductive effort depends on understanding the cause of the variations in fecundity in same-sized females, as well as knowing the maximum number of spawning that would be possible for a single female during one intermolt period in a particular breeding season. The capability of females of E. gonagra to spawn just after the larvae are released probably increases their reproductive investment.

Table 1. Reported fecundities for species of the genus Eriphia Latreille, 1817.

\begin{tabular}{|c|c|c|c|c|}
\hline Species & $\begin{array}{l}\text { Power function } \\
\qquad \mathbf{Y}=\mathbf{a} \mathbf{X}^{\mathbf{b}}\end{array}$ & Features of ovigerous females & Location & Reference \\
\hline Eriphia smithii & $\begin{array}{c}\mathrm{EN}=0.40 \mathrm{CW}^{3.08} \\
\mathrm{R}^{2}=0.94\end{array}$ & $\begin{array}{c}\mathrm{N}=29 \\
\mathrm{CW}=25.1 \text { to } 52.6 \mathrm{~mm} \\
\mathrm{NE} \text { variation }=5,923 \text { to } 73,501 \mathrm{eggs}\end{array}$ & Takeyama - Japan & Tomikawa and Watanabe (1992) \\
\hline Eriphia gonagra & $\begin{array}{c}\mathrm{EN}=2.68 \mathrm{CW}^{2.56} \\
\mathrm{R}^{2}=0.84\end{array}$ & $\begin{array}{c}\mathrm{N}=90 \\
\mathrm{CW}=17.7 \text { to } 43 \mathrm{~mm} \\
\text { NE variation }=2,720 \text { to } 36,192 \mathrm{eggs}\end{array}$ & Ubatuba - Brazil & Góes et al. (2005) \\
\hline Eriphia verrucosa & $\begin{array}{c}\mathrm{EN}=815.2 \mathrm{CW}^{2.65} \\
\mathrm{R}^{2}=0.35\end{array}$ & $\begin{array}{c}\mathrm{N}=31 \\
\mathrm{CW}=34.5 \text { to } 71.8 \mathrm{~mm} \\
\mathrm{NE} \text { variation }=15,229 \text { to } 224,165\end{array}$ & Sinop to Ordu - Turkey & Karadurmus and Aydin (2016) \\
\hline
\end{tabular}

$\mathrm{EN}=$ egg number; $\mathrm{CW}=$ carapace width; $\mathrm{N}$ = number of ovigerous females 
The processes of growth and reproduction compete for energy resources, and can therefore involve risks (Hartnoll, 1985). Variations in the period of time between molting and reproductive events allow for adjustments between the energy expended for reproduction and that expended for growth (Brody, 1991; Costa and Negreiros-Fransozo, 1998). This interpretation of the data allows us to formulate a hypothesis that larger individuals invest more energy in reproduction than smaller. However, analysis of RI for E. gonagra showed wide variations in the values for specimens of similar size. González-Pisani and López Greco (2014) observed similar variation in two species of spider crab which both presented significant amplitude in the number eggs related to body size, suggesting that external factors other than size affect fecundity. We propose this may be related to the occurrence of multiple spawning and the variation between different spawning during the same reproductive period.

We also observed that the mean values of $\mathrm{RI}$ in all size classes were very close to the total mean (11.31\%), with some discrepancies, but always less than the standard deviation. This suggests that the reproductive investment does not vary as a function of female size.

In addition, the allometric analysis of fecundity (Log number of eggs vs. Log carapace width) indicated the existence of negative allometry $(b<3)$, suggesting that the larger females invest less in egg production in proportion to their size. However, one must take into consideration that values of $b=3$ for isometry are used in analyses of the relationship between measurements with different patterns of variation, in this case the carapace width (a linear measurement) and the number of eggs (a volumetric measurement, in that the number of eggs depends directly on the relationship between the mean egg volume and the internal volume of the female carapace). Therefore, the use of the largest width of the carapace as a reference measurement for body size can lead to overestimates, since other measurements such as the length and height of the carapace are always smaller values. Because of this problem, it is worth questioning whether this relationship would tend toward isometry if the number of eggs and a mean value of the different reference measurements for body size were used, since the analyses comparing the weight of females and the number or weight of eggs indicated that these relationships are isometric, as observed by
Hines (1982) where the brood weight exhibited an isometric constraint to about $10 \%$ of body weight.

In some cases, after the puberty molt the female's growth rate decreases and most of the energy is directed toward reproduction (Costa and Negreiros-Fransozo, 1998). The analysis of the proportion of non-ovigerous adult females in each gonad development stage by size class, confirmed the hypothesis that smaller females invest less energy in reproduction, as females in the rudimentary gonad stage (RU) predominated in the first size classes of ovigerous females, and their number decreased as the crabs grew. Females in the developedgonad stage (DE) showed exactly the opposite, i.e., higher proportions in the larger size classes and fewer in the smaller classes. Females in the developing-gonad stage (ED), despite being less abundant than the others, had a higher frequency of occurrence in the intermediate size classes (29.2 to $33.4 \mathrm{~mm} \mathrm{CW})$. These results suggest that smaller adult females take longer to pass through the rudimentary gonad stage (RU) than do larger females. They are probably directing energy resources toward somatic growth, which can be a strategy to reach larger sizes more quickly and maximize egg production, as proposed by Hartnoll and Gould (1988). Thus, females that are capable of spawning again without an intervening copulation may increase production by minimizing the time required to produce more young, or may assure continued reproduction under stressful or hazardous conditions, when mating activity may be reduced (Morgan et al., 1983).

The present results indicate that the probability of finding a female in the DE stage is higher among the larger females than the smaller ones. The best explanation for this may be that smaller females spend most of the time growing, while larger females spend more time reproducing. This explanation is in accordance with the initial hypothesis, but the variation of the reproductive investment in relation to the crab size could not be evaluated by traditional procedures (using only one spawning).

\section{ACKNOWLEDGEMENTS}

We are grateful to CAPES (Coordenação de Aperfeiçoamento de Pessoal de Nível Superior) for Master's and Doctoral fellowships to the first author, and to FAPESP (Fundação de Amparo à Pesquisa do Estado de São Paulo) for financial support. 
We thank the NEBECC staff for helping during field and laboratory activities, and also the anonymous referees for their valuable comments. Sampling was carried out according to the Brazilian state and federal laws concerning wild animals. Thanks to Dr. Janet Reid for reviewing the manuscript.

\section{References}

Abelló, P. 1989. Reproduction and moulting in Liocarcinus depurator (Linnaeus, 1758) (Brachyura: Portunidae) in the northwestern Mediterranean Sea. Scientia Marina, 53: 127-134.

Adiyodi, K.G. and Adiyodi R.G. 1970. Endocrine control of reproduction in decapod Crustacea. Biological Reviews, 45: 121-165.

Andrade, L.S.; Góes, J.M.; Fransozo, V.; Alves, D.F.R.; Teixeira, G.M. and Fransozo, A. 2014. Differential habitat use by demographic groups of the red-finger rubble crab Eriphia gonagra (Fabricius, 1781). Brazilian Journal of Biology, 74: $1-10$.

Antunes, M.; Fransozo, V.; Castilho, A.L.; Cobo, V. J.; Teixeira, G.M. and Fransozo, A. 2015. Assessment of reproductive capacity in females of Callinectes danae Smith, 1869 (Brachyura, Portunoidea) during a period of high reproductive activity. Invertebrate Reproduction \& Development, 59: 9-16.

Biscoito, M.; Freitas, M.; Pajuelo, J.G.; Triay-Portella, R.; Santana, J.I.; Costa, A.L.; Delgado, J. and González, J.A. 2016. Sex-structure, depth distribution, intermoult period and reproductive pattern of the deep-sea red crab Chaceon affinis (Brachyura, Geryonidae) in two populations in the north-eastern Atlantic. Deep-Sea Research, 1: 99-114.

Branco, J.O. and Avilar M.G. 1992. Fecundidade em Callinectes danae (Decapoda, Portunidae) da Lagoa da Conceição, Florianópolis, Santa Catarina, Brasil. Revista brasileira de Zoologia, 9: 167-173.

Brante, A.; Cifuentes, S.; Portner, H.; Arntz, W. and Fernández, M. 2004. Latitudinal comparison of reproductive traits in five brachyuran species along the Chilean coast. Revista Chilena de Historia Natural, 77: 15-27.

Brody, M.S. 1991. Variation in reproductive output of the isopod, Armadillidium vulgare. p. 77-113. In: A. Wenner and A. Kuris (eds), Crustacean Egg Production. Rotterdam, A.A. Balkema.

Bryant, A.D. and Hartnoll, R.G. 1995. Reproductive investment in two spider crabs with different breeding strategies. Journal of Experimental Marine Biology and Ecology, 188: 261-275.

Cheung, T.S. 1968. Transmolt retention of sperm in the female stone crab Menippe mercenaria (Say). Crustaceana, 15: 117120.

Choy, S.C. 1988. Reproductive biology of Liocarcinus puber and L. holsatus (Decapoda, Brachyura, Portunidae) from the Gower Peninsula, South Wales. Marine Ecology, 3: 227-241.

Costa, T.M. and Negreiros-Fransozo, M.L. 1998. The reproductive cycle of Callinectes danae Smith, 1869 (Decapoda, Portunidae) in the Ubatuba region, Brazil. Crustaceana, 71: 615-627.

Curi, P.R. and Moraes, R.V. 1981. Associação, homogeneidade e contrastes entre proporções em tabelas contendo distribuições multinomiais. Ciência e Cultura, 33: 712-722.
Diesel, R. 1991. Sperm competition and the evolution of mating behavior in Brachyura, with special reference to spider crabs (Decapoda, Majidae). p. 145-163. In: R.T. Bauer and J. W. Martin (eds), Crustacean Sexual Biology. New York, Columbia University Press.

Du Preez, H.H. and McLachlan, A. 1984. Biology of threespot swimming crab Ovalipes punctatus (De Haan). III. Reproduction, fecundity and egg development. Crustaceana, 47: 285-297.

Flores, A.A.V. and Paula, J. 2002. Sexual maturity, larval release and reproductive output of two brachyuran crabs from a rocky intertidal area in central Portugal. Invertebrate Reproduction and Development, 42: 21-43.

Fransozo, A. 1986. Desenvolvimento larval de Eriphia gonagra (Fabricius, 1781) (Decapoda, Grapsidae), em laboratório. Revista brasileira de Zoologia, 4: 165-179.

Fransozo, A. and Negreiros-Fransozo, M.L. 1986. Influência da salinidade no desenvolvimento larval de Eriphia gonagra (Fabricius, 1781) e Sesarma (Holometopus) rectum Randall, 1840 (Crustacea, Decapoda), em laboratório. Revista Brasileira de Biologia, 46: 439-446.

Fransozo, A. and Negreiros-Fransozo, M.L. 1987. Morfologia dos primeiros estágios juvenis de Eriphia gonagra (Fabricius, 1781) e Eurypanopeus abbreviatus (Stimpson, 1860) (Crustacea, Decapoda, Xanthidae), obtidos em laboratório. Papéis Avulsos de Zoologia, 36: 257-277.

Fransozo, A. and Negreiros-Fransozo, M.L. 1991. Growth and age of three juvenile crab species (Crustacea, Decapoda, Brachyura). Papéis Avulsos de Zoologia, 37: 277-283.

Góes, J.M. and Fransozo, A. 1997. Relative growth of Eriphia gonagra (Fabricius, 1781) in State of São Paulo, Brazil. Nauplius, 5: 85-98.

Góes, J.M. and Fransozo, A. 1998. Heterochely in Eriphia gonagra (Fabricius, 1781) (Crustacea, Decapoda, Xanthidae) of the rocky coast from Praia Grande, Ubatuba (SP), Brazil. Biotemas, 11: 71-80.

Góes, J.M. and Fransozo, A. 2000. Sex ratio analysis in Eriphia gonagra (Crustacea, Decapoda, Xanthidae). Iheringia, Série Zoologia, 88: 151-157.

Góes, J.M.; Fransozo, A. and Fernandes-Góes, L.C. 2005. Fecundity of Eriphia gonagra (Fabricius, 1781) (Crustacea, Brachyura, Xanthidae) in the Ubatuba region, São Paulo, Brazil. Nauplius, 13: 127-136.

González-Pisani, X. and López Greco, L. 2014. Comparative reproductive effort and fecundity in the spider crabs, Leurocyclus tuberculosus and Libinia spinosa (Majoidea, Brachyura). Zoological Science, 31: 244-250.

Hartnoll, R.G. 1963. The biology of Manx spider crabs. Proceedings of the Zoological Society of London, 141: 423-496.

Hartnoll, R.G. 1982. Growth. p. 111-196. In: L.G. Abele (ed), The Biology of Crustacea. New York, Academic Press.

Hartnoll, R.G. 1985. Growth, sexual maturity and reproductive output. p. 101-128. In: A.M. Wenner (ed), Factors in Adult Growth. Rotterdam, A.A. Balkema.

Hartnoll, R.G. 1996. Reproductive investment in Brachyura. Hydrobiologia, 184: 31-40.

Hartnoll, R.G. and Gould, P. 1988. Brachyuran life history strategies and the optimization of egg production. Symposia of the Zoological Society of London, 59: 1-9. 
Hines, A.H. 1982. Allometric constraints and variables of reproductive effort in brachyuran crabs. Marine Biology, 69: 309-320.

Hines, A.H. 2011. Fecundity and Reproductive Output in Nine Species of Cancer crabs (Crustacea, Brachyura, Cancridae). Canadian Journal of Fisheries and Aquatic Sciences, 48: 267-275

Johnson, P.T. 1980. Histology of the Blue Crab Callinectes sapidus: A Model for the Decapoda. New York, Praeger Scientific Publishing Co, $440 \mathrm{p}$.

Jones, M.B. and Simons, M.J. 1983. Latitudinal variation in reproductive characteristics of a mud crab, Helice crassa (Grapsidae). Bulletin of Marine Science, 33: 656-670.

Karadurmus, U. and Aydin, M. 2016. An investigation on some biological and reproduction characteristics of Eriphia verrucosa (Forskål, 1775) in the South Black Sea (Turkey). Turkish Journal of Zoology, 40: 461-470.

Leme, M.H.A. 2006. Investimento reprodutivo e produção de ovos em desovas consecutivas do caranguejo Aratus pisonii (H. Milne Edwards) (Crustacea, Brachyura, Grapsoidea). Revista brasileira de Zoologia, 23: 727-732.

Leme, M.H.A. and Negreiros-Fransozo, M.L. 1998. Fecundity of Aratus pisonii (Decapoda, Grapsidae) in Ubatuba region. State of São Paulo, Brazil. Iheringia, Série Zoologia, 84: 73-78.

Mantelatto, F.L.M. and Fransozo, A. 1997. Fecundity of the crab Callinectes ornatus, 1863 (Decapoda, Brachyura, Portunidae) from the Ubatuba region, São Paulo, Brazil. Crustaceana, 70: 214-226.

Morgan, S.G.; Goy, J.W. and Costlow Jr, J.D. 1983. Multiple ovipositions from single matings in the mud crab Rhithropanopeus harrisii. Journal of Crustacean Biology, 3: 542-547.

Motoda, S. 1959. Devices of simple plankton apparatus. Memoirs of Faculty of Fisheries, Hokkaido University, 7: 73-94.

Reigada, A.L.D. and Negreiros-Fransozo, M.L. 1995. Fecundidade do caranguejo Hepatus pudibundus (Herbst, 1785) (Crustacea, Decapoda, Calappidae) em Ubatuba, (SP). Brazilian Archives of Biology and Technology, 38: 661-668.
Reigada, A.L.D. and Negreiros-Fransozo, M.L. 2000. Reproductive cycle of Hepatus pudibundus (Herbst, 1785) (Crustacea, Decapoda, Calappidae) in Ubatuba, SP, Brazil. Revista brasileira de Biologia, 60: 483-491.

Rotllant, G.; González-Gurriarán, E.; Fernández, L.; Benhalima, K. and Ribes, E. 2007. Ovarian maturation of the multi-spawning spider crab Maja brachydactyla (Decapoda: Majidae) with special reference to yolk formation. Marine Biology, 152: 383-394.

Santos, S. and Negreiros-Fransozo, M.L. 1997. Fecundity in Portunus spinimanus Latreille, 1819 (Crustacea, Brachyura, Portunidae) from Ubatuba, São Paulo, Brazil. Interciencia, 22: 259-263.

Somers, K. 1991. Characterizing size-specific fecundity in crustaceans. p. 357-378. In: F.R. Schram (ed), Crustacean Egg Production. Rotterdam, A.A. Balkema.

Subramonian, T. 1991. Chemical composition of spermatophores in decapod crustaceans. p. 308-321. In: R.T. Bauer and J.W. Martin (eds), Crustacean Sexual Biology. New York, Columbia University Press.

Sumpton, W. 1990. Biology of the rock crab Charybdis natator (Herbst) (Brachyura: Portunidae). Bulletin of Marine Science, 46: 425-431.

Tomikawa, N. and Watanabe, S. 1992. Reproductive ecology of the Xanthid crab Eriphia smithii McLeay. Journal of Crustacean Biology, 12: 57-67.

Vannini, M. and Gherardi, F. 1988. Studies on the pebble crab, Eriphia smithi MacLeay 1838 (Xanthoidea Menippidae): patterns of relative growth and population structure. Tropical Zoology, 1: 203-216.

White, J.F. and Gould, S.J. 1965. Interpretation of the coefficient in the allometric equation. The American Naturalist, 99: 5-18.

Wootton, R.J. 1979. Energy costs of egg production and environmental determinants of fecundity in teleost fishes. Symposia of the Zoological Society of London, 44: 133-159.

Zar, J.H. 1999. Biostatistical Analysis. New Jersey, Prentice-Hall, $663 \mathrm{p}$. 